\title{
PERSPEKTIF ISLAM DALAM KOMUNIKASI POLITIK KYAI \\ (Studi Etnografi Pengasuh Pondok Pesantren Annuriyyah \\ Jember Jawa Timur)

\author{
Ihwan Huda Al Mujib
} \\ Jurusan Bahasa, Komunikasi, dan Pariwisata, Politeknik Negeri Jember \\ J1. Mastrip Jember \\ mujib@polije.ac.id
}

\begin{abstract}
Kyai is a very influential figure in Islamic religion. Its influence is very large in society. The influence of the kyai in almost all fields. The magnitude of this influence has made many political aktors and state officials who do political communication. Kyai is a patron for political aktors and state officials who are clients. This research was conducted in Jember, East Java with a qualitative ethnographic method. The research subjects were selected based on purposive sampling. The clerics who are the subjects in this study are clerics who often accept political aktors and state officials. The results of the study showed that political communication by the kyai was inseparable from an Islamic perspective. Political communication conducted by the clerics face to face is inseparable from the dissemination of the yellow book in the boarding school. This proves that the life of the kyai cannot be separated from Islamic religious doctrines
\end{abstract}

Keywords: Islamic Perspective, Political Communication, Kyai.

\begin{abstract}
Abstrak
Kyai merupakan tokoh yang sangat berpengaruh dalam agama Islam. Pengaruhnya sangat besar dalam masyarakat. Pengaruh yang dimiliki kyai hampir disemua bidang. Besarnya pengaruh tersebut membuat banyak aktor politik dan pejabat negara yang sowan melakukan komunikasi politik. Kyai merupakan patron bagi aktor politik dan pejabat negara yang menjadi client. Penelitian ini dilakukan di Jember Jawa Timur dengan metode kualitatif etnografi. Subjek penelitian dipilih berdasarkan purposive sampling. Kyai yang menjadi subjek dalam penelitian ini merupakan kyai yang sering menerima aktor politik dan pejabat negara. Hasil penelitian menunjukkan bahwa komunikasi politik yang dilakukan kyai tidak lepas dari perspektif Islam. Komunikasi politik yang dilakukan kyai secara tatap muka tidak lepas dari pembejalaran kitab kuning yang ada di pondok pesantren. Hal ini membuktikan bahwa kehidupan kyai tidak lepas dari doktrin - doktrin agama Islam
\end{abstract}

Kata kunci: Perspektif Islam, Komunikasi Politik, Kyai. 


\section{PENDAHULUAN}

Kyai tidak bisa dilepaskan dari konstelasi politik Indonesia (Dhofier, 2015). Hal ini masih berlaku meskipun kyai tersebut telah memutuskan diri untuk tidak terjun dalam dunia politik (Huda, 2007). Lebih lanjut Huda (2007) menjelaskan bahwa pengaruh kyai sangat besar untuk legitimasi kewenangan para pemimpin. Keterlibatan kyai dalam dunia politik dibagi oleh Suprayogo (2007) dalam beberapa tipe. Aktif dan menjadi pengurus partai, kyai netral, dan kyai apatis.

Peran kyai dalam dunia politik masih menjadi perdebatan (Abdurrohim, 2008; Suprayogo, 2007). Aktifnya kyai dalam dunia politik tidak akan bisa lepas dari komunikasi politik dengan aktor politik dan pejabat publik (Mujib, 2018). Asumsi tersebut diperkuat oleh pengaruh kyai yang sangat besar dalam berbagai bidang di masyarakat (Dhofier, 2015). Alasan tersebut yang menjadikan para pelaku politik sering melakukan sowan kepada kyai untuk mencapai tujuan tertentu (Zulfiansyah, 2015). Sowan komunikasi politik tersebut bisa dimaknai sebagai komunikasi politik patron - client (Sahab, 2012). Hal ini dijelaskan oleh Kesuma (2013) bahwa komunikasi yang dilakukan tersebut ada sumber daya yang tidak seimbang diantara kyai dengan aktor politik, kyai mempunyai pengetahuan yang lebih tinggi dan pengaruh yang sangat besar dalam masyarakat. Sedangkan aktor politik dan pejabat negara sangat membutuhkan besarnya pengaruh kyai untuk tujuan tertentu.
Komunikasi politik kyai tidak merupakan komunikasi politik tatap muka. Hal ini sesuai dengan Inouguchi (2015) bahwa komunikasi politik dibagi menjadi tiga, komunikasi tatap muka, media social, dan media massa. Komunikasi politik tatap muka adalah komunikasi politik yang dilakukan secara langsung tanpa menggunakan media apapun dan keterampilan komunikasi merupakan kunci yang utama.

Komunikasi politik kyai tidak bisa lepas dari perspektif Islam (Mujib, 2018). Hal ini dikarenakan seluruh aspek kehidupan kyai tidak bisa lepas dari doktrin - doktrin ajaran agama Islam yang dilakukan sehari - hari (Dhofier, 2015). Doktrin - doktrin tersebut sesuai dengan isi dari kitab kuning yang diajarkan oleh kyai yang bersumber dari Al Quran dan hadist. Hal ini yang menjadi alasan kurang tepat ketika membahas kehidupan kyai menggunakan ilmu komunikasi perspektif barat.

Komunikasi Nonwestern perspektif masih belum banyak berkembang (Mujib, 2018). Komunikasi Non western perspective ini sangat penting dikembangkan untuk kemajuan ilmu komunikasi (Chen \& Starosta, 2003; Inouguchi, 2015). Hal ini dikarenakan perspektif timur mempunyai negara, kebudayaan, agama, dan bahasa yang sangat kompleks daripada perspektif barat (Chen \& Starosta, 2003). Hal ini yang menjadi landasan kurang tepat apabila menggambarkan komunikasi politik kyai menggunakan perspektif barat. Oleh karena itu, penulis akan menjelaskan bagaimana komunikasi politik kyai dengan aktor politik dan pejabat negara dalam perspektif Islam. 


\section{Komunikasi politik}

Cakupan komunikasi politik sangatlah luas. Inougichi (2015) meyatakan bahwa dalam konteks Asia komunikasi politik merupakan bahasan yang sangat luas sekali. Hal ini dikarenakan di konteks Asia komunikasi politik dalam diselidiki dalam setiap kebudayaan, nilai, agama, dan budaya yang ada dalam negara Asia (Miike, 2002). Penelitian ini berfokus pada komunikasi politik kyai yang merupakan tokoh agam Islam.

Inouguchi (2015) menjelaskan bahwa komunikasi politik dibagi menjadi tiga bagian. Pertama, komunikasi politik tatap muka. Komunikasi politik tatap muka merupakan hal yang wajar ditemui dalam kehidupan politik sehari - hari. Komunikasi politik ini sudah berkembang sejak jaman retorika Yunani yang sangat menekankan kemampuan berbicara depan umum. Kedua, komunikasi politik media masa. Komunikasi politik ini tidak bisa lepas dari media masa, baik cetak, radio, maupun televise. Menurut McNair (2002) komunikasi politik ini adalah proses penyampaian pesan yang telah disetting sedemikian rupa oleh para awak media. Ketiga, komunikasi politik media social. Internet telah mempermudah komunikasi saat ini, termasuk komunikasi politik. Sebagai teknologi baru, internet telah mengembangkan diri mempermudah komunikasi politik yang dilakukan oleh aktor politik dan pejabat negara kepada masyarakat atau stakeholder (Bode \& Darlympe, 2014). Bahkan internet dan media social yang ada didalamnya semakin dipilih oleh partai politik, aktor politik, dan pejabat negara dalam melakukan komunikasi politiknya.

\section{Komunikasi Politik Perspektif Islam}

Sejarah mencatat adanya hubungan yang erat antara Islam dan politik (Madjid, 2003). Hal ini bisa dilihat dari sejarah hijrahnya Nabi Muhammad dari Mekkah ke Madinah yang menjadi tonggak awal politik Islam (Saebani, 2007). Selain itu, beberapa ahli juga menyatakan bahwa Islam telah mempunyai peradaban politik yang maju meskipun terjadi pada masa klasik.

Pondok pesantren juga mempelajari komunikasi politik perspektif Islam. Hal ini terdapat dalam beberapa kitab kuning yang diajarkan dalam pembelajaran pondok pesantren. Beberapa kitab kuninng tersebut adalah Al Ahkam Al Shultoniah karya Imam Al Mawardi, Tanbihul Ghafilin karya Al Faqih Abu Laits Al Samaraqandi.

Al Mawardi menjelaskan dalam kitabnya terkait komunikasi politik. Umat Islam diharapkan meneruskan kepemimpinan Nabi dalam hal kenegaraan untuk menjaga kelestarian agama Islam (Al Mawardi, 1960). Lebih lanjut dijelaskan bahwa pemimpin harus membuat aturan aturan yang bisa diikuti oleh seluruh umat dan dikomunikasikan dengan baik. Selian itu, syariat Islam harus didahulukan ketika menjadi seorang pemimpin.

Al Samarqandi juga menjelaskan komunikasi politik dalam kitabnya. Seorang ulama tidak boleh terlalu mendekat kepada aktor politik dan pejabat negara (Samarqandi, 1986). Lebih lanjut dijelaskan disini adalah mendekat dalam artian memulai komunikasi politik terlebih dahulu. Hal ini dikarenakan apabila ulama atau kyai melakukan komunikasi terlebih 
dahulu tergolong keilmuan agamanya masih belum kuat.

\section{Patron Client Dalam Perspektif Islam}

Patron client mempunyai pengaruh yang sangat besar dalam dunia politik (Sahab, 2012). Hal ini disebabkan oleh hubungan yang tidak seimbang dalam dunia politik. Salah satunya adalah hubungan yang tidak seimbang antara kyai dengan aktor politik dan pejabat public. Seorang kyai memiliki sumber daya yang besar dibandingkan dengan aktor politik dan pejabat negara. Kyai mempunyai pengaruh yang sangat besar di masyarakat dan hal ini dibutuhkan oleh para politik dan pejabat negara.

Konsep patron client ini terjadi dalam komunikasi politik kyai. Namun penulis membahas konsep patron client ini dari perspektif Islam. Hal ini dikarenakan doktrin Islam yang selalu digunakan dalam kehidupan sehari - hari di pondok pesantren. Beberapa kitab kuning yang diajarkan di pondok pesantren tepat untuk membahas konsep ini dalam perspektif Islam.

Pertama, kitab Akhlaqulil Banin karya Umar bin Achmad Baradja. Kitab ini menjelaskan tentang kewajiban seorang client kepada patron. Patuh kepada nasihat patron, berniat mencari ridho Allah, sopan, memberikan salam, menerima dengan senang hati, setia. Sikap tersebut adalah beberapa sikap yang harus dimiliki oleh seorang client.

Kedua, kitab Ta'lim wal mutallim. Kitab yang disusun oleh Al Zarnuji menjelaskan beberapa syarat yang harus dimiliki oleh seorang patron (Sya'rony, 2007). Muallim, uswah, dan shaleh merupakan syarat utama yang harus dimiliki seseorang sehingga dianggap mampu menjadi seorang patron.

\section{METODE PENELITIAN}

Penelitian ini menggunakan metode penelitian kaulitatif. Untuk mendapatkan data yang dibutuhkan dalam penelitian ini, peneliti mengeluarkan seluruh kemampuannya sebagai pewawancara dan orang yang melakukan observasi agar mendapatkan data yang khas terkait permasalahan penelitian. Studi etnografi digunakan dalam penelitian ini. Etnografi digunakan untuk tujuan memberikan gambaran yang mendalam terkait subjek penelitian.

Penelitian ini dilakukan di Kabupaten Jember. Kabupaten Jember dipilih oleh peneliti dikarenakan masuk dalam wilayah Tapal Kuda Provinsi Jawa Timur yang masyarakatnya sangat patuh terhadap kyai dan besar pengaruhnya di masyarakat.

Penentuan dan pemilihan informan menggunakan teknik purposive sampling. Menurut Kriyantono (2006) teknik ini diambil oleh peneliti karena peneliti menganggap subjek penelitian dianggap sesuai dengan kriteria yang bisa menjawab permasalahan penelitian. Informan dalam penelitian ini adalah pengasuh pondok pesantren Annuriyyah Kaliwining Rambipuji Jember. Informan dipilih oleh peneliti dikarenakan telah terjun dalam dunia politik sejak masa orde baru. Selain itu, banyak pejabat Negara dari tingkatan pusat, provinsi, dan juga kabupaten melakukan sowan di kediaman beliau untuk meminta petunjuk, doa, dan dukungan terkait kegiatan politik yang dilakukan. 


\section{HASIL DAN PEMBAHASAN}

\section{Hasil}

Pondok pesantren Annuriyyah termasuk salah satu pondok pesantren tertua di Kabupaten Jember. Pesantren Annuriyyah berdiri sejak tahun 1928. Pesantren ini didirikan oleh K.H Muhammad Sholeh Syakir. Saat itu pondok pesantren masih berupa masjid dan kediaman kyai serta hanya memiliki beberapa santri. Pendiri pondok pesantren mendirikan pesantren setelah selesai menimba ilmu di Jombang kepada Alm. KH. Hasyim Asyari.

Pendiri pondok pesantren juga aktif dalam dunia politik. Pendiri pondok pesantren saat zaman kemerdekaan merupakan Panglima Hizbullah melawan penjajah. Hal ini diperkuat oleh surat dari PWNU Jawa Timur ketika beliau wafat yang menyatakan sebagai salah satu pahlawan di Jawa Timur. Selain itu, banyak koleksi Koran - Koran zaman kemerdekaan yang sampai saat ini masih tersimpan rapi sebagai bukti bahwa saat itu pendiri memang aktif dalam dunia politik. Aktifnya pendiri pondok pesantren dalam dunia politik juga diwariskan kepada salah satu putranya.

Saat ini pondok pesantren Annuriyyah diasuh oleh K.H Muhammad Nurru Sholeh Assyakirriy. Gus Nurru merupakan panggilan akrab beliau saat ini. Beliau merupakan putra ketujuh pendiri pondok pesantren. Sejak masa orde baru telah aktif dalam dunia politik.

Gus Nur sudah aktif dalam dunia politik sejak orde baru. Partai Persatuan Pembangunan merupakan partai yang diikuti saat itu. Hal ini dikarenakan PPP merupakan representasi warga NU dalam berpolitik saat itu. Nemun sejak orde baru runtuh, Gus Nur berpindah kendaraan politik. Gus Nur ikut bergabung dalam Partai Kebangkitan Bangsa (PKB) sampai saat ini. Gus Nur merupakan Pembina partai politik di tingkatan kecamatan.

Meskipun hanya menjadi Pembina di lingkup kecamatan, Gus Nur mempunyai pengaruh yang sangat besar di kancah politik nasional. Beberapa aktor politik nasional berkunjung ke kediaman Gus Nur. Aktor politik tersebut terdiri dari ketua umum partai politik, menteri, anggota DPR RI, calon gubernur, dan beberapa pengurus pusat partai politik. Gus Nur sangat terbuka dengan semua aktor politik yang ingin berkunjung ke kediamannya. Beberapa aktor politik dan pejabat Negara yang hadir di kediaman beliau mempunyai tujuan tujuan tertentu. Mulai dari sebatas silaturahim, meminta petunjuk, dan meminta dukungan politik.

Gus Nur melakukan beberapa tindakan dalam melakukan komunikasi politiknya. Pertama, meminta ijin mursyid ketika akan menerima aktor politik nasional dan lokal. Gus Nur telah melaksanakan Uzlah selama 5 tahun. Uzlah merupakan pengasingan diri untuk memusatkan perhatian kepada ibadah dan lebih mengurangi kegiatan duniawi. Gus Nur lebih banyak melakukan kegiatan dzikir, mengaji, dan sesekali mengajar santriwati pada pagi hari. Kegiatan Uzlah yang dilakukan oleh Gus Nur ini dibimbing oleh seorang kyai. Gus Nur menyebutnya sebagai mursyid.

Gus Nur selalu meminta ijin Mursyid ketika akan menerima aktor politik. Tanpa ijin mursyid, Gus Nur tidak akan 
mengijinkan aktor politik tersebut berkunjung. Hal ini dikarenakan Gus Nur tidak mau Uzlah yang dilakukannya beberapa tahun batal karena melanggar bimbingan mursyid. Beberapa aktor politik, pejabat Negara diijinkan oleh mursyid untuk bertemu Gus Nur. Namun tidak sedikit pula yang tidak mendapatkan ijin dikarenakan beberapa hal.

Kedua, Gus Nur memberikan amalan dzikir kepada aktor politik. Setelah mendapatkan ijin dari pembimbing Uzlah, Gus Nur melakukan komunikasi politik dengan aktor politik yang berkunjung ke kediaman beliau. Dalam komunikasi politik tersebut, Gus Nur selalu memberikan Ijazah dzikir kepada aktor politik. Ijazah merupakan amalan - amalan dzikir yang bisa diamalkan oleh aktor politik agar lebih dekat dengan Allah SWT dan urusan politiknya dipermudah.

Tidak semua aktor politik mendapatkan ijazah dzikir. Hal ini dikarenakan aktor politik yang datang berkunjung tidak semua beragama Islam. Beberapa aktor politik yang beragama Kristen juga berkunjung kepada Gus Nur. Ketika itu, Gus Nur hanya menjelaskan pandangan politiknya sesuai dengan perspektif Islam kepada aktor politik yang non muslim tersebut.

Ketiga, menjadikan anggota keluarga sebagai penyampai pesan politik. Datangnya aktor politik ke kediaman Gus Nur tidak lepas dari peran putra - putra beliau yang juga aktif dalam dunia politik. Ada dua putra Gus Nur yang aktif dalam dunia politik, Gus Abas dan Gus Beth. Kedua putra Gus Nur tersebut yang sering memfasilitasi aktor politik untuk berkunjung ke kediaman. Oleh karena itu,
Gus Nur selalu menyampaikan pesan politik melalui putra - putra beliau. Hal ini dilakukan karena Gus Nur tetap menjaga silaturahim meskipun aktor politik tersebut sudah tidak lagi berkunjung ke kediamannya.

\section{Pembahasan}

\section{Komunikasi Politik Gus Nur}

Ruang lingkup komunikasi politik sangat luas (Soukuop, 2014). Apalagi komunikasi politik di benua Asia yang memiliki banyak perspektif agama, budaya, nilai, kepercayaan, dan Negara (Inoguchi, 2015). Penelitian ini mencoba untuk menjawab permasalahan komunikasi politik pemuka agama Islam yang mempunyai pengaruh kuat dalam masyarakat dan termasuk dalam bidang politik.

Komunikasi politik kyai sangatlah menarik. Menurut Inoguchi (2015) komunikasi politik dibagi mejadi tiga. Komunikasi tatap muka, komunikasi politik media masa, dan komunikasi politik social media. Apabila kita mengacu pada pembagian yang telah dijelaskan tersebut, maka komunikasi politik yang dilakukan oleh kyai adalah komunikasi politik tatap muka. Hal ini dikarenakan Gus Nur sebagai seorang kyai melakukan komunikasi politik dengan menerima aktor politik dan pejabat negara di kediaman beliau. Mereka melakukan komunikasi tatap muka dengan membahas berbagai permasalahan politik yang aktual saat ini.

Menariknya adalah, komunikasi politik kyai juga dilakukan dengan perantara. Perantara ini adalah putra - putra kyai yang terjun dalam dunia politik dan menjadi fasilitator aktor politik untuk 
bertemu dengan kyai. Adanya perantara dalam komunikasi politik ini belum dibaha oleh Inoguchi sebelumnya. Kyai sebagai aktor politik dan tokoh yang berpengaruh di masyarakat pasti mempunyai tujuan tertentu mengapa melakukan hal itu. Selain itu, adanya distorsi pesan atau perubahan makna pesan yang disampaikan sangat mungkin terjadi dalam komunikasi politik kyai. Namun selama penelitian, peneliti tidak menemukan hal itu yang berarti komunikasi politik melalui perantara tidak menimbulkan masalah selama ini bagi kyai.

\section{Komunikasi Politik Gus Nur dalam Perspektif Islam}

Sebagai tokoh agama Islam, kyai merupakan patron bagi masyarakat terutama umat muslim. Seorang patron pasti menjadi tempat bertanya bagi client. Peran kyai sangat besar di masyarakat, besarnya peran tersebut berdampak kepkepada kyai yang menjadi tempat bertanya semua urusan duniawi dan akhirat masyarakat. Termasuk urusan politik para aktor politik dan pejabat negara. Aktor politik dan pejabat negara yang hadir di kediaman kyai, dapat dikatan sebagai client dari kyai.

Gus Nur menjadi patron bagi aktor politik dan pejabat negara yang hadir di kediamannya. Hubungan patron client ini terjadi karena ada kebutuhan besar dari client kepada patron (Maarif, 2010). Gus Nur menjadi patron karena dianggap sebagai tokoh yang mampu memberikan kebutuhan atas pemecahan masalah yang dihadapi oleh aktor politik dan pejabat negara yang hadir. Pandangan yang disampaikan Gus Nur sangat dibutuhkan.
Hal ini tidak lepas dari kemampuan beliau dalam berbagai bidang.

Syarat sebagai patron sudah dimiliki oleh Gus Nur, yaitu Muallim. Muallim adalah orang mempunyai pengetahuan dan kemampuan yang lebih dalam suatu bidang. Gus Nur sebagai seorang kyai tentu memiliki hal ini. Tidak hanya dalam bidang agama, namun juga dalam bidang politik. Keahlian tersebut kemudian dikomunikasikan dengan para aktor politik yang hadir. Termasuk memberikan amalan dzikir kepada aktor politik dan pejabat publik.

Namun Gus Nur juga menjadi seorang client dalam komunikasi politknya. Gus Nus masih sangat hormat dan patuh kepada Mursyid yang membimbingnya saat uzlah. Gus Nur tidak berani melakukan komunikasi politik apabila tidak diijinkan oleh Mursyid. Hal ini merupakan sifat Tawadhu' yang wajib dimiliki oleh client kepada patron. Sikap tersebut juga dijelaskan dalam kitab Ta'lim wa mutaallim.

Uswah juga tersiratkan dalam komunikasi politik Gus Nur. Uswah merupakan sikap menjaga diri dari larangan dalam melaksanakan kegiatan bagi seorang patron. Beberapa kitab telah menjelaskan bahwa ulama dilarang untuk mendekat kepada para penguasa. Al Zarnuji (1983) dalam kitabnya Ta'lim wa mutaallim dan larangan tersebut juga ada dalam kitab Tanbihul Ghofilin. Sikap Uswah Gus Nur ditunjukkan dengan menjadikan anggota keluarga sebagai penyambung pesan politik ketika melakukan komunikasi politik dengan aktor politik dan pejabat negara. 
Komunikasi politik Gus Nur sangat merefleksikan komunikasi politik perspektif Islam. Beberapa tindakan komunikasi politik tidak lepas dari ajaran ajaran Islam yang ada dalam kitab - kitab kuning yang diajarkan di pondok pesantren dan bersumber pada $\mathrm{Al}$ quran dan hadist.

\section{PENUTUP}

\section{Simpulan}

Komunikasi politik yang dilakukan Gus Nur sangat merefleksikan komunikasi perspektif Islam. Semua tindakan komunikasi politik bersumber kepada kitab - kitab kuning yang diajarkan di pondok pesantren dan bersumber kepada Al Quran dan Hadist Nabi Muhammad Saw. Oleh karna itu, sangat sulit untuk membahas komunikasi politik kyai menggunakan teori - teori barat. Hal ini dikarenakan keunikan - keunikan yang ada dan kehidupan pesantren sangat kental dengan doktrin Islam.

\section{Saran}

Penulis menyarankan kepada peneliti selanjutnya untuk lebih mendalami komunikasi politik perspektif Islam. Hal ini dikarenakan masih sangat banyak keunikan -keunikan lain dari komunikasi politik kyai yang belum dibahas dalam artikel ini. Selain itu, masih banyak kitab kitab kuning di pondok pesantren yang menjelaskan tentang komunikasi politik.

\section{DAFTAR PUSTAKA}

Abdurrohim, M. S. (2008). Iklamul Munaddimin. Rembang: Pustaka Alba

Al Mawardi. (1960). Akhkamul Shultoniah. Beirut: Darul Fikr.
Al Zarnuji. (2001). Ta'lim Mutallim al Thariq Al Ta'allum. Semarang: Pustaka Alawiyah.

Bode, L., \& Dalrympe, K. E. (2015). Politic in 140 Character or Less: Campaign Communication, Network Interaction, and Political Participation on Twitter. Journal of Political Marketing, 1-22.

Chen, G. M., \& Starosta, W. J. (2003). Asian Approaches to Human Communication: A Dialogue. Intercultural Commucation Studies, 12(4), 1-15.

Dhofier, Z. (2011). Tradisi Pesantren. Jakarta: LP3ES.

Huda, N. (2007). Islam Nusantara Sejarah Sosial Intelektual Islam di Indonesia. Jogjakarta: Ar-Ruzz Media Grup.

Inouguchi, T. (2015). My Humble Thoughts on Political Communication Research in Asia. Asian Juornal for Public Opinion Research, 2(4), 228-247.

Kesuma, G. C. (2011). Pesantren dan Kepemimpinan Kyai. Jurnal Sosioteknologi. 12(6), 139-145.

Kriyantono, R. (2007). Teknik Praktis Riset Komunikasi. Jakarta: Kencana Prenada Media.

Maarif, S. (2010). Pola Hubungan Patron Client Kyai dan Santri di Pesantren. Ta'dib. 15(2), 273-295).

Madjid, N. (2003). Islam Agama Kemanusiaan: Membangun Tradisi dan Visi Baru Islam Indonesia. Jakarta: Paramadina. 


\section{JURNAL NOMOSLECA}

Volume 6 Nomor 1, April 2020

McNair, B. (2002). An Introduction To Political Communication: Third Edition. London: Sage Publisher.

Mujib, I. H. (2018). Komunikasi Keluarga Pesantren dalam Pembelajaran Politik dan Proses Penentuan Afiliasi Politik. Malang. Brawijaya.

Sahab, A. (2012). Politik Patron Client di Sampang. Jurnal Jejaring Administrasi Public. II (8). 1-7.

Soukup, S. J. (2014). Political Communication. Communication Research Trends. 33. 2-24.

Suprayogo, I. (2009). Kyai dan Politik Membaca Citra Politik Kyai. Malang. UIN Press Malang.

Sya'roni. (2007). Model Relasi Ideal Guru Murid. Jogjakarta: Sukses Offset.

Zulfiansyah, M. A. (2015). Budaya Sowan Kyai, Sebuah Strategi dalam Komunikasi Politik. Skripsi. Universitas Brawijaya. 